\title{
By everyone and for everyone: The principles underlying 'justice' in Deuteronomy 16:18-20
}

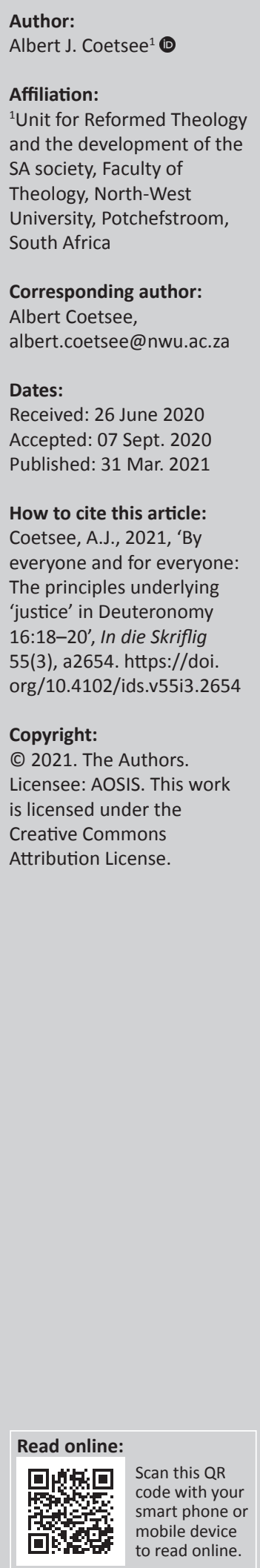

\section{Author:}

Affiliation

'Unit for Reformed Theology SA society, Faculty of Theology, North-West University, Potchefstroom, South Africa

Corresponding author: Albert Coetsee,

Dates: Accepted: 07 Sept. 2020

How to cite this article: Coetsee, A.J., 2021, 'By The principles underlying 'justice' in Deuteronomy 16:18-20', In die Skriflig 55(3), a2654. https://doi. Copyright:

C 2021. The Authors is licensed under the Creative Commons Attribution License.
In Deuteronomy 16:18-20, Moses instructs the people of Israel to appoint judges and officials in their various towns upon entering the Promised Land. Strikingly, not much is said about the qualifications of these judges and officials, or the method of their appointment. Rather, the passage is devoted to what these judges and officials were, and were not to do, and also what the community's share in justice was to be. Despite the emphasis in the passage on the principles the community and its judges and officials were to embody, no comprehensive study has been published that relates what exactly was expected of both parties when it comes to justice. The primary objective of the current article was to investigate what principles these judges and officials were to embody, and what was expected of the community when it came to justice. The secondary objective was to give some suggestions on how these principles can be applied to modern citizens and judiciaries. This article investigates the possible literary, historical and canonical context of the passage by means of a detailed literature study and an independent exegetical study. Making use of these findings, the principles underlying justice in the passage were deduced. This article revealed that the appointment of judges and officials was the task of the whole community; that judges and officials were to judge fairly; that the community had to appoint judges and officials who were wise; that the appointment of judges and officials was for the whole community; that the pursuit of justice were to be the aim of everyone and that the blessing of the Lord would ensue where justice prevails. In conclusion some suggestions were given on how these principles can be applied to modern citizens and judiciaries, briefly reflecting on judicial progress and challenges in South Africa.

Contribution: This article therefore contributed to the discussion of the Old Testament in Africa. It argued that one possibility of meeting the challenges and setbacks of the South African judiciaries is to (once more) emphasise the principles deduced from Deuteronomy 16:18-20 to the country's citizens and judiciaries. The (re)implementation of these principles by the Rainbow Nation could ensure that justice is served by everyone and for everyone.

Keywords: Deuteronomy 16:18-20; justice; righteousness; judges; officials; judge; judiciary, principles; community; citizens.

\section{Introduction}

In Deuteronomy 16:18-20, ${ }^{1}$ Moses instructs the people of Israel to appoint judges and officials in their various towns upon entering the Promised Land:

\footnotetext{
${ }^{18}$ You shall appoint judges and officials throughout your tribes, in all your towns that the Lord your God is giving you, and they shall render just decisions for the people. ${ }^{19}$ You must not distort justice; you must not show partiality; and you must not accept bribes, for a bribe blinds the eyes of the wise and subverts the cause of those who are in the right. ${ }^{20}$ Justice, and only justice, you shall pursue, so that you may live and occupy the land that the Lord your God is giving you. ${ }^{2}$
}

Strikingly, not much is said about the qualifications of these judges and officials, or the method of their appointment (cf. Tigay 1996:160). Rather, the passage is devoted to what these judges and officials were and were not to do. As such, the passage provides a glimpse of the key principles these judges and officials were to embody (cf. Wright 1996:204).

In the same breath, the passage also contains principles specifying the community's share in justice. Addressing the people of Israel and not the judges and officials per se, the principles the 1.Further on all references to Deuteronomy $16: 18-20$ will be indicated only by verse numbers.

2.All English translations come from the New Revised Standard Version (NRSV), unless otherwise indicated. 
judges and officials were to embody are intertwined with what was expected of Israel with regard to their judges and officials, and justice in general.

Despite the emphasis in the passage on the principles the community and its judges and officials were to embody, no comprehensive study has been published that relates what exactly was expected of both parties when it comes to justice. The primary aim of the current article is to do exactly that, namely to investigate what was expected of the community and its judges and officials in relation to justice. The secondary aim is to give some suggestions on how these principles can be applied to modern citizens and judiciaries.

The article starts by investigating the possible literary, historical and canonical context of the passage. Next, the principles underlying justice in the passage are deduced, forming the bulk of the article. The article concludes by giving some suggestions on how these principles can be applied to the modern citizens and judiciaries, briefly reflecting on judicial progress and challenges in South Africa. By doing this, the article contributes to the discussion of the Old Testament in Africa. ${ }^{3}$

\section{The literary, historical and canonical context of Deuteronomy 16:18-20 The place of the passage within Deuteronomy}

Verses 18-20, which can easily be identified as a passage by its content and the markers in the Hebrew text, ${ }^{4}$ is part of the specific legislation found in the book of Deuteronomy (cf. Dt 12-26). More specifically, it forms the introduction or starting point of the larger Deuteronomy 16:18-18:22, ${ }^{5}$ which contains legislation on civil and religious administration in Israel (Block 2012:399; cf. McConville 2002:281). ${ }^{6}$ Deuteronomy 16:18-18:22 identifies four 'offices' of power and leadership (Brueggemann 2001:178; cf. O’Brien 2008:155), namely judges (16:18-17:13), the king (17:14-20), priests (18:1-8) and prophets (18:9-22), and elaborates on some of their tasks and responsibilities. Some view this larger unit as an elaboration on the fifth commandment (Christensen 2001:353; cf. Merrill 1994:257; Wright 1996:203), especially in light of the concluding words of the passage, 'that it may go well with you in the land that the Lord your God is giving to you' (Dt 5:16).

Three sub-units can be identified within the larger Deuteronomy 16:18-17:13, forming a chiasma: the first

\footnotetext{
3.This article was initially prepared as a paper for a conference on the impact of the Bible on the South African society, hosted by the Theological School Potchefstroom in collaboration with the Faculty of Theology of the North-West University, 28-29 January 2021 in Potchefstroom
}

4.See the setumah at the end of verses 17 and 20 .

5.Christensen (2001:353) enlarges the range of this block of material, arguing that Deuteronomy 16:18-21:9 elaborates on laws regarding leadership and authority in ancient Israel.

6.Brueggemann (2001:178-179) succinctly refers to Deuteronomy 16:18-18:22 as 'the covenantal deployment of public power', with the larger Deuteronomy 16:18$18: 22$ indicating 'a covenantal vision of public power'. Accordingly, Brueggemann (2001:179) argues that the passage refers to 'covenantal justice'. discusses the appointment of judges and officials (Dt 16:18-20), whilst the last elaborates on the authority of the Levitical priests and judges and the compliance expected of the people (Dt 17:8-13). The sub-unit sandwiched in the middle, prohibits certain forms of worship and idolatry (Dt 16:21-17:7). ${ }^{7}$

The fact that verses 18-20 is in the emphatic first position within the larger Deuteronomy 16:18-18:22, indicates that, apart from being 'a fitting introduction to the larger section on political and religious leadership in ancient Israel' (Christensen 2001:361), the principles for civil and religious administration as given here, form the foundation of all judgement in ancient Israel. It may also apply in some way to all the 'offices' as discussed in the legislation that follows.

\section{The structure of the passage}

Verses 18-20 begins with the main exhortation of the passage: Israel were to appoint judges and officials, and these were to render just decisions for the people (v. 18). This is followed by three examples of what these judges and officials were not to do (v. 19). The passage ends by contrastingly stating what the main aim of Israel and its judges and officials should be (v. 20a), followed by the promise that, doing this, would result in life and the inheritance of the Promised Land (v. 20b). An overview of the structure of the passage can be seen in Figure 1.

Christensen (2001:361) sees a chiastic structure in the passage with the emphasis on verse 19. This is supported by the inclusio formed by the use of the verb give (נֵָ)ן. ${ }^{8}$ A basic view of the possible chiastic structure of verses $18-20$ can be seen in Figure 2.

Whilst the basic chiastic structure is noted, the content of the passage seems to emphasise verses 18a and 20a rather than verse 19 (cf. Block 2012:401-402). The emphasis of the passage falls on the call to appoint judges and officials (v. 18a), and the exhortation that the pursuit of justice should be the aim of everyone, namely Israel and its judges and officials (v. 20a). This is supported by the fact that

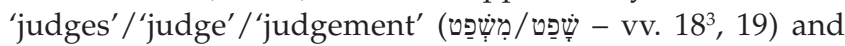

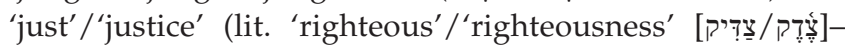
vv. $18,19,20^{2}$ ) are the key words of the passage, found four times each, as well as the fact that these key words are found in the emphatic first position of verse 18 (lit. 'judges and officials' [you shall appoint]) ${ }^{9}$ and verse 20 (lit. 'justice,

7.Some scholars view Deuteronomy 16:21-17:1 or the whole of Deuteronomy 16:2117:13 as 'intrusive', arguing that it does not fit the context and was probably added later (cf. Block 2012:401; Lundbom 2013:519; Rofé 2001:92-93). But this is not necessarily the case as the chiasma identified above indicates. Moreover, McConville (2002:288) argues that judicial passages 'interspersed with cultic ones' corresponds to the nature of Deuteronomy, whilst the prosodic analysis of Deuteronomy 16:1817:1 by Christensen (2001:361), supports the inclusion of Deuteronomy 16:2117:1. For a discussion of the logic behind the arrangement of laws in Deuteronomy 16:18-18:22, see Tigay (1996:453-454).

8.The inclusio is either formed by the very first and very last words of the passage, namely 'you shall give [i.e. appoint] judges and officials for you' and 'the land that the Lord your God is giving you', or the fact that the phrase that the Lord your God the Lord your God is giving you', or the fact the the pour God inclusio is formed by the verb 'give' (נֵֵָ)

9.Verse 18 is also emphasised by means of alliteration (cf. the use of the Hebrew

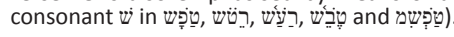




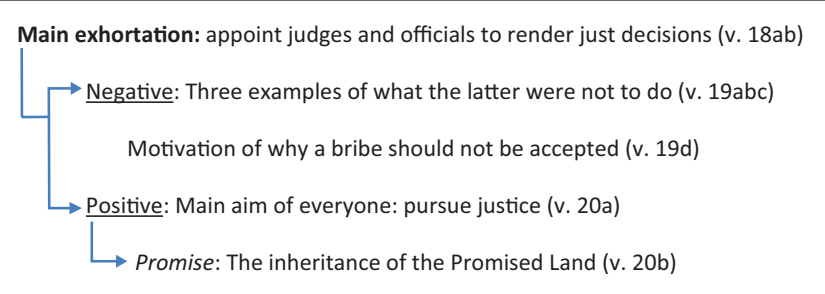

FIGURE 1: The structure of Deuteronomy 16:18-20.

What Israel should do: appoint judges and officials (v. 18)

What the judges and officials should not do (v. 19)

What Israel should do: pursue righteousness (v. 20)

FIGURE 2: The basic chiastic structure of Deuteronomy 16:18-20.

justice' [you shall follow]), with repetition in the latter signifying exclusivity.

The analysis of the structure of verses 18-20 reveals another important aspect of the passage: the passage employs the second person singular throughout. The third person plural is found only once at the end of verse 18 to describe the function of the judges and officials: 'they shall

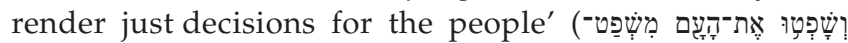
(צֶ). The implication is that Israel as a whole, namely as a corporate personality, is addressed throughout the passage, and not simply the judges or officials. This is especially striking in verse 19 , which addresses the judges and officials on what they should not do. Whilst this is unmistakably the primary meaning, the use of the second person singular in verse 18 purposefully blurs the subject in verse $19,{ }^{10}$ implying that the people too were not to do the things prohibited here (cf. Vogt 2006:210). This is supported by the seamless transition to the use of the second person singular in verse 20 where it is clear that Israel as a whole is addressed.

\section{The historical and canonical context of the passage}

Reading the Torah from a canonical context, it is clear that pre-Deuteronomy 16 passages presuppose the existence of judicial procedures in Israel (McConville 2002:281). The most important passage that links on to and influences the interpretation of verses 18-20, is Deuteronomy 1:9-18.

Deuteronomy 1:9-18, which seems to echo Exodus 18:13-27 (cf. Flatto 2018:492), describes how Moses, on the advice of his father-in-law Jethro, appointed 'leaders' (ראש) and 'commanders' (שِ) shortly after the exodus from Egypt to hear easier cases and to judge the people alongside him, thereby lightening his burden. Strikingly, Deuteronomy 1:16

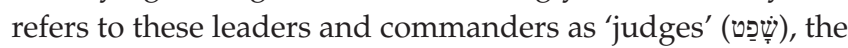
same word used in Deuteronomy 16:18. How the judges and officials that were to be appointed, according to Deuteronomy

10.Unlike the Masoretic Text (MT), the Septuagint (LXX) makes use of the third person plural in verse 19, explicitly indicating that the judges and officials are the subject. Nonetheless, the use of the third person 'supports the view that the community continues to be addressed in vv. 19 and 20' (Vogt 2006:211).
16:18-20 fit into the bigger judiciary of ancient Israel, should therefore be investigated.

Taking the canonical context of the various passages in the Torah as they present themselves as departure points, the reconstruction of the development of the judiciary in ancient Israel can be traced along the following three stages:

- Before, in and after Egypt: in patriarchal times, judicial matters were dealt with within the family structure with the man as head of the family, and elders as the heads of families and tribes (cf. Lundbom 2013:520; Rofé 2001:95). The authority of the latter most probably 'arose from their spontaneous recognition by the people' (Rofé 2001:95). This practice continued during Israel's years in Egypt as well as the time thereafter, with the elders 'always' being 'a component of leadership of the people' (Frymer-Kenski 2003:988).

- In the wilderness: shortly after the exodus from Egypt, Moses appointed leaders and commanders to judge the people alongside him (Ex 18:13-27; Dt 1:9-18). From the words employed in Deuteronomy 1:9-18, these judges seem to have 'doubled as military commanders' (Lundbom 2013:520; cf. Morrow 1995:170). ${ }^{11}$ The appointment of these leaders and commanders did not replace the elder-based judiciary, but functioned as a dual but complementary judicial system (Block 2012:402;12 McConville 2002:287; cf. Morrow 1995:170). This is evidenced by the judiciary role that Deuteronomy still attaches to elders after the envisioned conquest of the Promised Land (Dt 19:12; 21:19-20; 22:15-18; 25:7-9), and the prescriptions of certain cases where elders and judges were to work together (Dt 21:1-9). In other words, 'the rights of the patriarchal leadership of old Israel' were still 'recognised' (McConville 2002:287). The case at hand determined whether the elders or judges were consulted (Block 2012:402). In general, it seems like elders decided local matters of a family or the community which were simple and clear, whilst the judges decided more difficult and complex matters (cf. Dt 17:8). ${ }^{13}$

- In the Promised Land: the judicial system established in the wilderness was envisaged to continue in the Promised Land. Deuteronomy 16:18-20 witnesses to this practice, referring to the appointment of judges and officials in

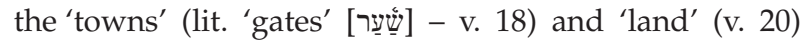
that the Lord was giving to Israel. Consequently, it seems like verses 18-20 reconstitutes or modifies Deuteronomy 1:9-18 'for agrarian life within the system of cities and

11. Weinfeld (1977:68), in the same vein, argues that the executive staff of the king was mostly recruited from the military, and that ' $[t]$ he royal judges acted in accordance with their military rank' (p. 73).

12.Block (2012:403) argues that Deuteronomy assumes 'that kinship-based triba structures and a settled agrarian life will coexist in Israel'.

13.A discussion of the judiciary in ancient Israel during the period in the wilderness will not be complete without mention of the Covenant Code's reference to certain legal procedures that should take place 'before God' (cf. Ex 21:6; 22:8, 9 [some interpret the Hebrew noun god in these contexts as 'judges']), and the appointment of 70 elders to (spiritually) support Moses in his burden (cf. Nm 11:16-17, 24-25). For a discussion of the former, see Durham (1987:321, 326); also see Cole 2000:191) for the latter. The influence of these passages for the reconstruction of the development of the judiciary in ancient Israel, however, is not as influential as Exodus 18:13-27 and Deuteronomy 1:9-18. 
towns in pre-monarchic Israel' (Christensen 2001:361; Lundbom 2013:520; Otto 2016:1464; cf. Merrill 1994:257). The new element of the laws found in verses 18-20 is the appointment of judges and officials who should seek justice 'in local courts' (Christensen 2001:362) in order 'to provide for a judiciary throughout the land' (McConville 2002:282-283). ${ }^{14}$ In the Promised Land, the Levitical priests were to work together with the judges in certain cases in order to aid them in judgement (Dt 17:9, 12; 19:17; 21:5). The latter is envisioned to take place at the place that the Lord will choose' (Dt 17:8, 10), implying the centralised sanctuary or temple. It seems that ' $[d]$ ispersed authority amongst local judges' were to exist 'alongside some centralised authority' (Olson 2007:54), with the latter dealing with difficult cases (Flatto 2018:492; Weinfeld 1977:75). ${ }^{15}$

The reconstruction as given above is based on the canonical context of verses 18-20. Critical scholarship, however, proposes other reconstructions for the judiciary in ancient Israel as well as the historical context of verses 18-20 within this reconstruction (cf. Otto 2016:1439-1447, 1459). ${ }^{16}$ For the purposes of this study, the reconstruction as given above is used as a departure point. ${ }^{17}$

Concerning the identity of the judges and officials in verses 18-20, the following can be deduced:

- The word used for 'judge' (a participle of the verb refers to 'actions that restore or preserve order in society so that justice, especially social justice, is guaranteed' (Schultz in VanGemeren 1997.4:214). Consequently, a 'judge' is somebody who ensures that order and justice prevails. In the immediate context, the 'judge' of Deuteronomy 16 seems to refer to some kind of 'specialised' (Tigay 1996:160) or 'professional judge' (Lundbom 2013:520), but not professional in the sense of the modern word (Block 2012:402; cf. Christensen

14.McConville (2002:282) indicates that this is the only law in the Torah "providing explicitly for a judiciary in the localities'

15.O'Brien (2008:165) convincingly argues that the central sanctuary did not function as 'a "high court" to which one who disagrees with the ruling of a "lower" or "loca court" may appeal. Nor does the court at the central place have the authority to override local decisions. It is only for cases that the addressee decides cannot be resolved at the local level' (Lohfink 1993:340; cf. O’Brien 2008:171).

16.Lohfink (1993:343), for example, summarises that ' $r$ recent biblical scholarship agrees on the thesis that all the laws concerning offices are not of the same verses 18-20 was added after the exile to bolster the reforms of King Josia This verses 18-20 was added after the exile to bolster the reforms of King Josiah. This seems improbable, for it is clear that a civil judiciary existed in Israel's cities befor the time of Josiah (McConvilles 18-20 are 'spirtual and religious' rather that poltical (Block 2012:399). Others argue that verse 19 circulated independently of the present context as model fo judges (Christensen 2011:363; cf. Morrow 1995:166). Whilst this is not impossible, as is evidenced by the various passages that echo the prohibitions of verse 19 , it seems improbable, for verse 19 is 'not marked off structurally as a separate unit' (McConville 2002:281). Still, others note the parallels between verses $18-20$ and the reforms of King Jehoshaphat ( $2 \mathrm{Chr} 19: 1-11)$ and come to certain conclusions (Morrow 1995:170; Rofé 2001:101-107; cf. Weinfeld 1977:65-66). It seems as if Jehoshaphat in his reforms reinstated the old practice of appointing judges and exhorted them to judge fairly (Lundbom 2013:521; cf. McConville 2002:282). For synchronic approaches of the historical context of Deuteronomy 16:18-18:22, see Carrière (2001) and O'Brien (2008:155-172).

17.Weinfeld (1977:86) goes to the other extreme by arguing that we cannot 'trace any changes or developments in judicial procedure in Israel', as 'a common judicial pattern prevailed in the ancient Near East from at least the middle of the second millennium B.C. onward', and we do not have sufficient data to reconstruct the development. In fact, Weinfeld $(1977: 88)$ refers to the quest for the historical setting of, amongst others, verses $18-20$ as 'senseless'.
2001:363; Morrow 1995:167). Their 'professional' status resides in the fact that they were envisaged to interpret more difficult cases than the elders. These judges were probably appointed from amongst the elders of the city, ${ }^{18}$ and their commission included other aspects of leadership (Tigay 1996:160).

- The root of the participle translated as 'officials' (שטר) refers to 'writing' or 'arranging', and is frequently used with reference to the army to refer to subordinate officials engaged primarily in scribal work (Lundbom 2013:521; Rofé $\left.2001: 98^{19}\right)$. Consequently, 'officials' apparently refer to the subordinate personnel employed under judges (Lundbom 2013:521), namely assisting officials fulfilling secretarial functions (Weinfeld 1977:83). ${ }^{20}$ According to Weinfeld (1977:84), the officials assisted the judge by functioning as 'a secretary for recording, a constable for executive-punitive measures, and a messenger or attendant for rendering service to the court' [Weinfeld's emphasis]. These officials, however, were not 'low-ranking officials, functionaries or strongmen who execute the judges' orders, but holders of higher office' (Rofé 2001:96-97). ${ }^{21}$ They, too, had the task of administering justice by assisting the judges.

The possibility exists that the Hebrew words judges and

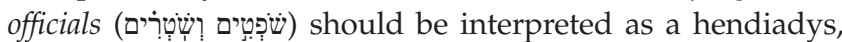
referring to one office (cf. Frymer-Kenski 2003:988; Rofé 2001:98-99; Vogt 2006:209), namely 'judging officials' (Merrill 1994:258) or 'scribal judges' (Block 2012:402). This is indirectly supported by the fact that the Hebrew nouns judges (שָפְ̣ט) and officials (שָטִִרים) sound similar, and that the only task described in the context is judging (Merrill 1994:258). However, as Deuteronomy in some contexts refers to officials without any mention of the judges (Dt 20:5, 8, 9; 29:10; 31:28), this cannot be proven beyond reasonable doubt. Moreover, most English versions of the Bible translate 'judges' and 'officials' as two separate entities (e.g. NRSV; English Standard Version [ESV]; King James Version [KJV]; New International Version [NIV]). Consequently, this study does the same.

\section{The principles underlying justice in Deuteronomy 16:18-20}

The analysis of the literary, historical and canonical context of verses 18-20 confirms that the passage does not say much about the qualifications of the judges and officials, the method of their appointment or the practical detail of their job description. There is 'no attempt to regulate details of a judicial system', as Lundbom (2013:520) puts it. Rather, the passage devotes its attention to the principles these judges and officials were to embody, and what was expected of

18.Frymer-Kenski (2003:987), who briefly surveys the identity of judges in the Oid Testament, indicates that judges could be commanders, elders or 'anyone else who sat to hear petitions and cases.

19. Rofé (2001:98) argues that these officials were 'essentially civilian', and 'had no place whatever in the army command'.

20.Craigie (1976:247) refers to the officials as 'the executive branch of the law'.

21.Rofé (2001:98-99) himself, however, views the phrase 'judges and officials' as a hendiadys. 
Israel with regard to their judges and officials. The emphasis falls on moral requirements rather than technical detail (Wright 1996:204).

This fits into the bigger aim and scheme of Deuteronomy. Deuteronomy presents itself as three speeches by Moses on the plains of Moab to the second generation of Israelites who were on the brink of entering the Promised Land. The aim of these speeches is to give the hearers a theological perspective on the past, and to exhort them to obey and serve the Lord wholeheartedly. As such, the aim of Deuteronomy is to exhort, to motivate, and to change perceptions and conduct. This explains why verses 18-20 is 'homiletical' (Lundbom 2013:525) in nature and provides 'broad principles of judicial propriety that' the judges and officials 'are to follow' (Tigay 1996:160).

This section of the article investigates what was expected of the community and its judges and officials when it comes to justice according to verses 18-20. The following six principles are deduced:

\section{The appointment of judges and officials is the task of the whole community}

Verse 18 starts with the exhortation: 'You shall appoint judges and officials.' Literally, the text reads: 'Judges and officials you are to give to you.' As supported elsewhere in the Hebrew Bible, the combination of the verb give (נָָּן) with the prepositional pronoun connotes 'to make/appoint a person(s) for a specific function or position' (Grisanti in VanGemeren 1997.3:209; cf. Labuschagne in Jenni \& Westermann 1997:785). In the context of verse 18, the interpretation and translation of the verb as 'appoint' is fitting (cf. amongst others NRSV; ESV; NIV; New American Standard Bible [NASB]; New King James Version [NKJV]).

The appointment of these judges and officials is to be done by 'you' (singular). As determined above in the discussion of the structure of the passage, verses 18-20 employs the second person singular throughout, indicating that Israel as a whole, namely as a corporate personality, is addressed. In other words, the people were to appoint these judges and officials; it was the task of the community. Vogt (2006:210) correctly stresses that 'the significance of this ... has not been as readily appreciated'. Presumably the judges and officials were selected from amongst the local elders (or Levites [so Christensen 2001:361, comparing Dt 17:9]) on the basis of some sort of popular consent of the people; amongst others, 'their community reputation for fairness' (Olson 2007:52), with other elders acting on behalf of the people with their appointment (Block 2012:402; Christensen 2001:361; McConville 2002:286; Tigay 1996:160, 364; Weinfeld 1977:87; cf. Wright 1996:204). Whatever the case may have been in practice, the text indicates that the burden of appointment rests on the shoulders of the people. ${ }^{22}$

22.In contrast, Rofé (2001:94-96) argues that local judges were appointed by a centra authority.
As scholars have indicated, this emphasis on the responsibility of the community is radical and revolutionary (McConville 2002:281; cf. Vogt 2006:209). Vogt (2006) fittingly states:

Throughout the ancient Near East, the king was responsible for the administration of justice, but Deuteronomy places this responsibility squarely in the hands of the community as a whole. (p. 211)

Consequently, the first principle that can be deduced from the passage is that the appointment of judges and officials is the task of the community. The community was called upon to be involved in the appointment of these office bearers (Otto 2016:1462) and, per implication, to supervise the faithful execution of their duties. The people were to know who were able and fitting candidates, and appoint them. ${ }^{23} \mathrm{At}$ their appointment, the people could repeat to appointees what they were supposed to do (Lundbom 2013:522). During their term of service, the people could reflect on the conduct of their judges and officials and, if necessary, remind them of the principles they were to embody. Knowing from childhood what was expected of judges and officials, newly elected judges could start office with a firm conviction of their role and mandate (cf. Tigay 1996:160).

This principle stresses the community's calling to be actively involved in the maintenance and pursuit of justice. Block (2012:399) fittingly refers to the passage as 'a call for communal commitment to righteousness'. Ensuring that justice prevails was not a task of a select few; it was the task of the community (cf. Block 2012:401).

The remainder of verse 18 stresses this fact. Two phrases suggest that the whole community was to be involved in the appointment of judges and officials:

- 'in all your gates': literally, verse 18 refers to the appointment of judges and officials 'in all your gates'

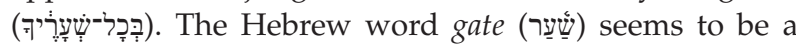
metonymy for towns or 'walled cities' (Weinfeld 1977:66), whilst, at the same time, referring to the location of judicial proceedings (Block 2012:403; cf. Rt 4:1ff.). This twofold use of 'gates' seems deliberate (Otto 2016:1461). The inclusivity of the phrase, however, should be noted. Israel were called to appoint judges and officials 'in all your gates', meaning everywhere. Judges and officials were not only to be appointed in certain parts of the country or in major cities, but everywhere throughout the land (cf. Christensen 2001:363).

- 'according to your tribes': linking on the previous, verse 18 instructs the people to appoint judges and officials

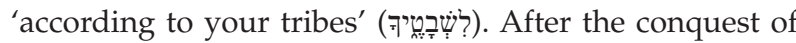
the Promised Land (as recorded in the book of Joshua), Israel will be organised and settled according to their tribes (cf. McConville 2002:287). All these tribes were to have judges and officials according to verse 18, supporting the interpretation of judges and officials distributed everywhere throughout the land (cf. Lundbom 2013:521).

23.The calling of the community in the appointment of office bearers is also found in Deuteronomy 17:15, where the people are supposed to appoint the king that the Lord chooses. In contrast to this, according to Deuteronomy 18:5 and 15-18, God appoints the priest and prophet (McConville 2002:286; cf. Otto 2016:1437). 
Both phrases imply that the responsibility for the maintenance of righteousness is distributed throughout the land. There is no absolutism in the sense of one region or city having exclusive (appointing) power, dictating who should be appointed (cf. Brueggemann 2001:179). Wright (1996) succinctly says in this regard:

At a basic level, the administration of justice in Israel was largely a matter of local people in every town judging themselves through local people elected or appointed for the purpose. (p. 204) $)^{24}$

In sum, the first principle that can be deduced from verses 18-20 concerning justice is that the appointment of judges and officials is the task of the whole community.

\section{Judges and officials are to judge fairly}

The final words of verse 18 state the function of the judges and officials: 'and they shall judge the people with righteous judgment'. Whilst most English versions translate the conjunction linking these two sentences (?) with 'and' (cf. NRSV; ESV; NIV; KJV; NKJV; NASB), which is indeed the most common and natural translation, it can be understood to denote result or purpose (cf. Brown, Driver \& Briggs 1977:254.1). ${ }^{25}$ If this is the case, the sentence states: 'You shall appoint judges and officials ... so that they shall render just decisions for the people.'

All the same, this clause makes it clear what the judges and officials were to do: they were to 'render just decisions for the people'; literally 'to judge the people with righteous

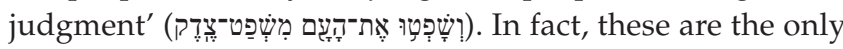
explicit words in the passage that elucidate their duties. Strikingly, Block (2012:403) indicates that although

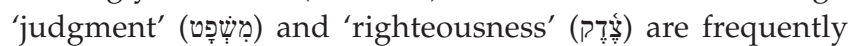
found together in the Hebrew Bible, the phrase 'righteous judgment' occurs only here.

The governing word in this phrase is righteous ( (צָ ), which seems to refer to what is 'right', 'just' (Brown et al. 1977:841.2), 'correct', 'straight' or 'communally beneficial' (Koch in Jenni \& Westermann 1997:1046) according to some standard (Reimer in VanGemeren 1997.3:746). In the current context, 'righteous judgment' most probably refers to judgement which is 'fair' (Block 2012:403; Wright 1996:204) or 'correct' (cf. Lundbom 2013:521). The phrase seems to be comprehensive, referring to the execution of the task of the judges and officials in such a way that they are 'scrupulously fair' (Merrill 1994:258), providing 'totally correct judgment' (cf. Christensen 2001:363; Morrow 1995:171). ${ }^{26}$ Taking Deuteronomy as a whole, this type of judgement would be based on 'covenantal standards as outlined in the Torah' (Block 2012:403; cf. Vogt 2006:212).

\footnotetext{
24.Christensen (2001:364) correctly indicates that the passage seems to reflect the ' $[e]$ quality of all citizens under the law, regardless of class or status'.
}

25.Morrow (1995:166) views verse 18b as a result clause given the change of subject.

26.Lohfink (1993:339) translates verse 18b with 'these must administer an impartial judgment to the people'.
Linking on to the prescription of righteous judgement in verse 18, verse 19 gives three examples of what the appointed judges and officials were not to do. Although the flow of the passage indicates that the people, too, were not to do these things (as indicated in the analysis of the structure of the passage above), the judges and officials are addressed in the first place. In what follows, it is argued that the three negative practices that the judges and officials were not to do, strengthens and supports the positive description of their task as stated in verse 18: they were to judge the people fairly.

The three clauses prohibiting certain practices on the part of the judges and officials are introduced with the Hebrew adverb indicating negation (לא). What the judges and officials were not to do, are the following:

- Distorting justice: literally, verse 19a prohibits the

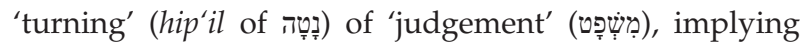
perverting or wresting justice (cf. Brown et al. 1977:641.1), turning aside anyone's right in judgement (Gesenius \& Tregelles 2003:546) or subverting justice (Hamilton VanGemeren 1997.3:92). The phrase is used a number of times in the Torah to prohibit the perversion of justice by siding with the many (Ex 23:2) or failing the poor, sojourner, fatherless or widow in their lawsuit (Ex 23:6; Dt 24:17; 27:19).

- Showing partiality: the phrase you must not show partiality in verse $19 \mathrm{~b}$ literally prohibits 'regarding' or

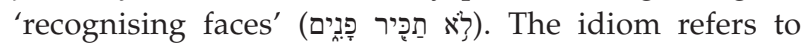
treating someone in a certain way because of his appearance; that is, who he or she is. Translating the phrase as 'showing partiality' is therefore fitting. Verse $19 \mathrm{~b}$ exhorts the judges and officials to judge fairly without any form of bias, prejudice or favouritism. Although Lundbom (2013:523) is correct by indicating that this specific phrase is found only in Deuteronomy $(1: 17 ; 16: 19)$ and Proverbs $(24: 23 ; 28: 21)$, partiality is prohibited throughout the Hebrew Bible by means of various words or phrases. The Torah teaches that Israel was not to be partial to the poor man in his lawsuit (Ex 23:3) or defer the great (Lv 19:15), whilst the judges that Moses appointed in the wilderness are exhorted not to be partial in judgement (Dt 1:17). The Wisdom Literature reflects that it is not good to be partial to the wicked (Pr 18:5) or to show partiality at all (Pr 24:23; 28:21). One psalm (Ps 82:2) bemoans that Israel's judges judge unjustly and show partiality to the wicked.

- Accepting a bribe: Israel's judges were not to accept bribes. Literally, they were not to 'take' (לְָָ) a 'present' or 'gift' (שَin), specifically a gift for which something is expected in return (Christensen 2001:363; Tigay 1996:161), namely a 'bribe' (cf. Grisanti \& McCann in VanGemeren 1997.4:75-76). ${ }^{27}$ The last clause in verse 19 states why judges and officials were not to accept bribes: 'for a bribe blinds the eyes of the wise and

27.Tigay (1996:161) indicates that even if the word gift is used in the neutral sense of 'fee' in verse 19 (his choice), it is prohibited, for it 'would inevitably incline the judge in that party's favor' (see also Frymer-Kenski 2003:992-993). 
subverts the cause of those who are in the right'. Whilst there is some debate about the interpretation of the final words, ${ }^{28}$ the meaning of the sentence is clear: Israel's judges and officials were not to accept bribes, for a bribe would make the judges and officials biased. Moreover, those that will be able to manipulate the judiciary with bribes, are the wealthy and powerful, ensuing that the poor and vulnerable - precisely those in need of fair judgement- will suffer (Brueggemann 2001:180; cf. Craigie 1976:247; Lundbom 2013:523). Elsewhere in the Torah, the taking of bribes is explicitly prohibited (cf. Ex 23:8, ${ }^{29}$ Dt 27:25). The Wisdom Literature reflects on the wickedness of the practice (Pr 17:23; Ec 7:7; cf. Ps 15:5), whilst the prophets, unfortunately, accuse Israel of committing this crime repeatedly (Is $1: 23$; 5:23; 10:2; 33:15; Jr 5:28; Ezk 22:12; Mi 3:11; 7:3; Am 5:12; Ml 2:9).

The three practices that were not to be done by the judges and officials are clearly condemned throughout the Hebrew Bible. Strikingly, albeit unsurprisingly, these practices are also condemned in judicial writings of the ancient Near East. ${ }^{30}$ The most striking negative parallel in the Hebrew Bible is arguably 1 Samuel 8:3, which states that Samuel's sons, who were made judges over Israel by their father, turned aside after gain, took bribes and perverted justice (in stark contrast to Samuel himself [cf. 1 Sm 12:3-5]).

Moving from Israel to their God, it is striking to note that his attributes include impartiality and the inability to take a bribe. In a list of attributes that emphasise the Lord's uniqueness, Deuteronomy 10:17-18 states that God is not partial and takes no bribe, but (fairly) executes justice for the fatherless and widow. A similar list of divine attributes in 2 Chronicles 19:7 emphasises that there is no injustice, partiality or taking of bribes with the Lord. Consequently, by not doing the practices prohibited in Deuteronomy 16:19, the judges and officials would be reflecting and imitating the character of their God.

Put together, the three negative practices that the judges and officials were not to do indicate that they were to judge fairly in everything. They were to administer justice without any form of distortion, corruption, prejudice, favouritism, partiality, dishonesty or influence. They were to reflect the

28.The final words of verse 19 indicate that a bribe literally twists/perverts/overturn the words/matters of the righteous' (ויסלר דברי צדיקדיקם). What this phrase refers to, the can be the righteous, presumably referring to the overall purpose the righteous aim to achieve, namely justice or righteousness (cf. Lundbom 2013:523), whilst the NIV and KJV render it as 'twists/perverts the words of the righteous', implying the judges and officials are the righteous ones referred to here or, rather, supposed to be. The latter interpretation could be supported by the phrase blinds the eyes of the wise - if the two phrases form a parallelism. The phrase can also be understood to refer to 'the words of righteous individuals, presumably litigants or witnesses in the case' (Lundbom 2013:524), or 'the cause of those who are in the right' (NRSV; cf. Lohfink 1993:339; McConville 2002:287). Whatever the case may be, as a whole, the phrase refers to the miscarriage of justice (McConville 2002:288).

29.The parallel between verse 19 and Exodus 23:8 is striking, although Morrow (1995:166) indicates that ' $[t]$ his need not imply that Exod 23:8 is dependent on Deut 16:19 or vice versa'.

30. For parallels in ancient Near Eastern literature prohibiting these practices, see Weinfeld (1977:65-88), Lundbom (2013:522-525) and Otto (2016:1463). Weinfeld $(1977: 80)$ indicates that the elements that are most common in these writings are the prohibition of showing partiality, taking bribes and distorting justice. character of the Lord by judging fairly. This is the second principle that can be deduced from this passage.

\section{The community should appoint judges and officials who are wise}

Verse 19 's elaboration on three practices that the judges and officials were not to do, indirectly reveal an attribute that should characterise every judge and official. The verse states that the judges and officials were not to take bribes, for a

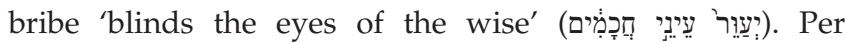

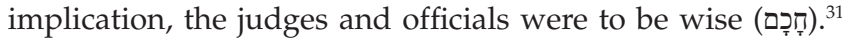
They were to be known for their intellectual and practical wisdom (Lundbom 2013:525; Olson 2007:53; cf. Tigay 1996:161). This is supported by Deuteronomy 1:13-15, which states that the leaders and commanders that were appointed shortly after the exodus were 'wise' (דָָָָם), 'discerning/

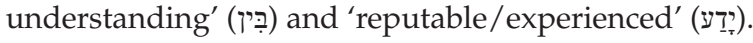

In light of their mandate, the necessity of Israel's judges and officials possessing intellectual and practical wisdom is obvious. Fair judgement requires a vast amount of discernment and understanding, both of human nature and what is right and fitting in a number of varying circumstances. ${ }^{32}$ In order to hone their discernment, Deuteronomy undoubtedly expected of Israel's judicial leaders to abide 'strictly by the divine commandments' (Müller 2013:29).

Consequently, the third principle that can be deduced from verses 18-20 concerning justice is that those appointed as judges and officials were to be wise, namely known for their intellectual and practical wisdom.

\section{The appointment of judges and officials is for the whole community}

The description of the task of the judges and officials makes it clear that their appointment was not an end in itself. Rather, their appointment was a means to a greater purpose. Put differently: they were not appointed just for the sake of being appointed and their appointment was not merely a matter of status or power. They were appointed for a specific task or function, and that was to judge people fairly. They had the mandate to ensure that justice prevailed amongst the people. The servanthood of the judges and officials is on the foreground.

Whilst the judges and officials undoubtedly had authority to fulfil their mandate, their authority was grounded on the ultimate Authority who commanded their appointment (Brueggemann 2001:179; cf. Craigie 1976:248; McConville 2002:282) and, per implication they were accountable before Him for their judgement.

Consequently, the fourth principle that can be deduced from the passage is that the appointment of judges and officials

31.For the possible relationship between verses 19-20 (especially the phrase blinds the eyes of the wise) and Wisdom Tradition, see Müller (2013:9-33).

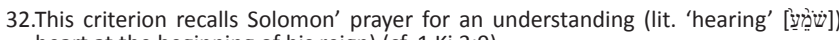
heart at the beginning of his reign) (cf. 1 Ki 3:9). 
was for the community. In order for Israel to be the people they were called to be, order, structure and justice was indispensable. This the judges and officials were to serve them with. And, linking on the first principle deduced above, this faithful administration of justice was meant for the whole community.

\section{The pursuit of justice should be the aim of everyone}

The list of negative practices that the judges and officials were not to do is followed by the positive exhortation in verse 20: 'Justice, and only justice, you shall pursue.' A closer investigation of the phrase reveals the following:

- The standard Hebrew word order of verb-subject-object is changed to object-verb/subject in order to emphasise the first words and object of the sentence, ${ }^{33}$ namely 'justice' (צ̧).

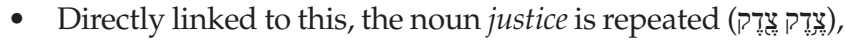
indicating exclusivity. ${ }^{34}$ Most translations render this exclusivity either with repetition (cf. 'justice, [and] only justice' [NRSV; ESV; NASB]; 'justice and justice alone' [NIV]), or an intensive form (cf. 'that which is altogether just' $[\mathrm{KJV}]) .{ }^{35}$

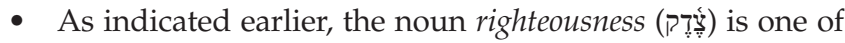
the key concepts of the passage (vv. 18, 202; cf. עצ in v. 19), and refers to what is 'right' or 'correct' according to some standard. In this context, the noun is used substantively. At first glance, the noun seems to refer to the 'abstract quality that underpins' just 'decisions, namely justice' (McConville 2002:287). Closer investigation, however, suggests that the noun is used in a broader sense. Although including the concept of social 'justice' in the judicial sense, the noun in verse 20 seems to refers to the encompassing concept of 'righteousness' (Vogt 2006:212). Support for this interpretation lies in the fact that Israel as a whole is addressed in this context, not merely the judges and officials (Vogt 2006:212), ${ }^{36}$ and the issues addressed in the immediate context 'range far beyond social justice, from personal morality to idolatry' (Block 2012:399). Consequently, verse 20 calls the whole community to be committed to and to promote righteousness as defined by the Torah (Block 2012:401).

- The verb pursue (רזר) literally refers to the action of actively and purposefully pursuing, chasing or persecuting someone. In verse 20 , it is used figuratively to refer to 'earnestly following after' or 'pursuing' justice (Brown et al. 1977:922.2; Gesenius \& Trefelles 2003:758). Whilst various translations opt to translate the verb with

33.The standard Hebrew word order in verse 20 would have been "You shall follow

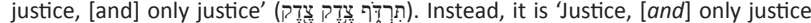

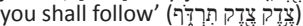

34.Gesenius (1910: $\$ 123 e$ ) refers to repetition of this kind 'express[ing] an exceptional or at least superfine quality', with the repetition serving 'to intensity the expression to the highest degree'.

35.Morrow (1995:164) translates the phrase with 'real justice'.

36 .Vogt (2006:212-213) argues that ' $[f]$ ew of the people being addressed are likely to engage in the adjudication of cases as judges. But all of the people have opportunity to pursue 'follow' (cf. ESV; NIV; [N]KJV), 'pursue' seems more fitting and striking (cf. NRSV; NASB). The imperfect form of the verb indicates a mandatory prescription.

The structural analysis above indicated verse 20a as one of the phrases emphasised in the passage, and this is supported by a more detailed investigation. Moreover, the structural analysis found that the use of the second person singular in verse 20 indicates that both Israel and their judges and officials are addressed. These words climactically indicate what the aim of both Israel and its office bearers should be when it comes to justice: all of them were to pursue righteousness (which includes justice), and righteousness alone (cf. Craigie 1976:248). All of them were to do what is right, fair and reasonable according to the Torah.

Consequently, the fifth principle that can be deduced from the passage is that the pursuit of justice should be the aim of everyone. Justice is asked for throughout this passage and by everyone.

\section{The blessing of the Lord ensues where justice prevails}

The final words of verses 18-20 indicate what the result will be when Israel and its judges and officials pursue justice: 'Justice, and only justice, you shall pursue, so that (לְמֵַע) you may live and occupy the land that the Lord your God is giving you' (v. 20, [author's emphasis]).

These words link both 'life' and the inheritance of the Promised Land to the pursuit of justice. 'Life' in this context refers to 'well-being or quality of life' (Coetsee 2019:111), ${ }^{37}$ whilst the inheritance of the Promised Land includes the long-term retention thereof. Viewed as a whole, verse $20 \mathrm{~b}$ seems to refer to quality of life in the Promised Land for which a prerequisite is the pursuit of justice (cf. Tigay 1996:161). ${ }^{38}$

These words, however, should not be understood mechanically. Read within the context of the whole of Deuteronomy, the passage does not state that if Israel merely pursues justice, they will automatically receive and retain the Promised Land. These words are addressed to a covenant community within the framework of the covenant made by their God. Moreover, these words are personal. The text says that the Lord is giving the Promised Land to them. He is actively at work with their inheritance and retention of the Promised Land. Israel's responsibility, as part of their covenantal relationship with the Lord, is covenantal loyalty, which is, amongst others, expressed by the pursuit of justice or, as indicated above, the more encompassing term righteousness. The Lord blesses the covenantal loyalty of Israel with quality of life in the Promised Land (cf. Wright 1996:205).

37.Life is often linked to obedience and the inheritance of the Promised Land in Deuteronomy (cf. $4: 1 ; 5: 33 ; 6: 24 ; 8: 1 ; 30: 6,15-20$ ).

38.McConville (2002:286) argues that the appointment of judges and officials is 'seen as a response to the divine gift of land'. 
That the Lord blesses Israel's pursuit of justice, is supported by various passages in the Hebrew Bible that emphasise that the Lord loves righteousness or justice, practices it and does not pervert justice (cf. Gn 18:25; Dt 32:4; Is 61:8; Ps 11:7; 33:5; 89:14; 99:4; Job 8:3; 32:14; 37:23; Dn 9:14, etc.). Consequently, by pursuing justice, Israel and its judges and officials reflect the character of their God.

Taking all the above into consideration, the sixth principle that can be deduced from the passage is that the blessing of the Lord ensues where covenantal justice prevails.

\section{Applying these principles to modern citizens and judiciaries}

Having determined what was expected of the community and its judges and officials when it comes to justice according to verses 18-20, the article concludes by giving some suggestions on how these principles can be applied to modern citizens and judiciaries, briefly reflecting on judicial progress and challenges in South Africa. Such an attempt not only seems viable, but also enriching, as some scholars view Deuteronomy 16:18-18:22 as a 'significant precursor of some of the principles of democratic government, especially the separation of powers' and plea for the integrity of the judicial system (cf. Lohfink 1993:346-347; Wright 1996:203).

\section{Some caveats}

When applying the principles of verses 18-20 to modern citizens and judiciaries, the following caveats should be noted:

\section{Applying an ancient text in a modern context}

Bridging the context of Deuteronomy to the modern day, always runs the risk of being superficial and focusing on what the interpreter would like to emphasise. Verses 18-20 refers to the judges and officials the people of Israel were to appoint during a specific stage of their history. These judges and officials are not the same as their modern-day professional counterparts. Moreover, modern legislation can be extremely complex with a legion of nuances and subtleties in need of judiciaries that are both capable and professional. Also, legislation and the mandates of judiciaries differ around the world. All these differences should be taken into account when applying verses 18-20 in the modern day. Nevertheless, as the emphasis of the passage falls on the principles the judges and officials were to embody intertwined with what was expected of Israel with regard to their judges and officials, these principles can be applied to various contexts. ${ }^{39}$ Although the application of these principles may differ from context to context and culture to culture, the heart of the principles remains the same.

\section{More is required in the modern context}

Deuteronomy 16:18-20 in no way addresses all aspects pertaining to the constitution, mandate, power and gatekeepers

39.Lohfink (1993:339) fittingly states that, whilst verses 18-20 does not provide a model 'that can be simply transposed', 'we may perhaps learn to what things we must always pay heed concerning the distribution of the functions of power'. of a judiciary. The passage, for example, does not mention criminal jurisdiction or the detail thereof. Nor does the text address the modern day qualifications needed to serve as part of a judiciary. As could be expected, the concept of the separation of church and state as we have it today is absent in Deuteronomy 16:18-20 (cf. Lohfink 1993:339). These 'gaps' should be filled in a modern society with detailed and unambiguous criteria and legislation.

\section{The ideal situation versus reality}

Deuteronomy 16:18-20 envisions the ideal situation where judges and officials are perfect, and the community's conduct toward their judges and officials is exemplary. Consequently, the passage is referred to by Block (2012:399) as the 'utopian constitution of Israel' (cf. Lohfink 1993:346). ${ }^{40}$ To expect a modern day community to perfectly embody these principles, would therefore be naive. Moreover, the fact that the passage commands the pursuit of justice by judges, officials and the community suggest that justice did not always prevail in Israel. In fact, the strong prohibition of certain practices in the passage suggests that judges and officials often misused their position and power, and that the people (especially the poor) suffered because of this. In order to rectify and to prevent this, Deuteronomy provides the principles that judges, officials and the community were to strive for. In other words, whilst Deuteronomy 16:18-20 paints the perfect picture, it does this knowing that whilst we do not live in an ideal world, a visualisation of this is necessary for people to know what they should strive for. ${ }^{41}$

\section{The principles of Deuteronomy 16:18-20 for modern citizens and judiciaries}

The principles deduced in Deuteronomy 16:18-20 can be translated into the following for modern citizens and judiciaries:

\section{The calling of citizens: Appoint judges who are wise and able}

Citizens are called to appoint those serving on the judiciary; it is primarily their task. This implies that citizens should know who has the abilities (amongst others intellectual and practical wisdom) and willingness to serve in the various capacities of a judiciary, and elect them. Whilst practical reasons make it impossible for each citizen to know the eligibility of each electee, and whilst it is fitting that a government body formally attend to their appointment, sustentation and accountability, the foundational calling of the citizens should not be outsourced: as a corporate personality, citizens of a country are in some way to be actively involved in the appointment of those serving on the judiciary, and to hold them accountable via the appropriate channels.

40.For scholars who regard Deuteronomy 16:18-18:22 as a 'constitution' for Israel, see the references in McConville (2002:281) and Vogt (2006:205). In the same vein, Flatto (2018:490) argues that Mishnaic accounts of judicial administration based on the Pentateuch are 'undeniably utopian'.

41.In this regard, McConville (2002:287) fittingly states that 'Deuteronomy knows that the existence of statute and due process, though necessary, is no guarantee of right practice. 


\section{The calling of the judiciary: Judge fairly and serve all citizens}

The judiciary is called to judge all citizens fairly in everything, thereby serving all citizens. Firstly, their judgement should be fair or correct. It should be based on a certain agreed upon benchmark (like a constitution), and measured against this standard. Any form of bias, prejudice, partiality, corruption, favouritism, or the like should be absent from their judgement. Secondly, the judiciary should render fair judgement in all cases brought before them. In the modern context this would refer to fair judgement in both lower and higher courts, and in matters pertaining to civil and criminal law. Thirdly, the fair judgement the judiciary is to render in everything is meant for everyone. It is for the poor and vulnerable as well as the wealthy and powerful. Finally, by judging all citizens fairly in everything, the judiciary will fulfil the primary reason for their appointment: to serve all citizens.

\section{The calling of everyone: Pursue justice in everything}

Whilst the rendering of fair and correct judgement is the calling of the judiciary, both the judiciary and the citizens are called to pursue justice in everything. Everyone should do what is right, fair and reasonable in every conceivable situation. This not only implies that citizens are to purposefully strive to conduct themselves according to a certain standard but also that, they are to aid the judiciary by letting justice prevail as far as possible in their own circles. Again, the definition of what is right, fair and reasonable should be based on and measured against a certain benchmark (e.g. a constitution).

\section{The result of pursuing justice: The blessing of the Lord will ensue}

Both citizens and the judiciary can expect the blessing of the Lord to ensue if justice prevails. Of course, not all citizens will have a faith commitment to the God revealed in the book of Deuteronomy. But those citizens and members of the judiciary that do, will follow their judicial calling with the knowledge that they are doing these things in obedience to the Lord, reflecting his character and gracefully expecting his blessing.

\section{Reflecting on judicial progress and challenges in South Africa}

As could be expected of a modern judiciary, South Africa has a number of different types of courts. ${ }^{42}$ By way of summary, the lower courts include the Magistrate's courts (consisting of regional and district courts), whilst the higher courts include the High Court, the Supreme Court of Appeal and the Constitutional Court. A little more than a quarter of a century ago in 1994, the Constitutional Court became the highest court in South Africa. As is made clear by its name, the Constitutional Court is founded on the Constitution of the Republic of South Africa, ${ }^{43}$ and deals with relations

42. For a general survey of the South African judiciary and its most important aspects, see Hoexter and Olivier (2014).

43.The first edition of the Constitution was accepted in 1993, whilst the curren edition came into effect in 1997. between individuals, or institutions and the state. ${ }^{44}$ From 1994, all South African higher courts have constitutional jurisdiction, with the Constitutional Court 'awarded exclusive jurisdiction on some constitutional matters' (Venter 2020:174).

Since the introduction of the constitutional status of the judiciary in South Africa, remarkable progress has beenmade in South African judiciaries, but not without various challenges and setbacks (Venter 2020:172). These include political influence, veiled ideological motivations of government, attempts by government to interfere in the executive affairs of judiciary, explicit opposition to judicial restraints on government conduct, non-compliance of the state and 'transformation' (cf. Venter 2020:179-186). Thankfully, despite these various challenges, the Constitutional Court has survived these challenges 'by consistently providing well-reasoned and accessible judgments' (Venter 2020:194).

In my view one possibility of meeting these challenges is to (once more) emphasise the principles deduced from Deuteronomy 16:18-20 to the citizens and judiciary of South Africa. The citizens of the Republic of South Africa as a corporate personality should, in some way, be actively involved in the appointment of those serving on the judiciary. The judiciary should be reminded that they should judge all citizens fairly in everything and thereby serve the citizens. Both the judiciary and citizens should do what is right, fair and reasonable according to the constitution in every conceivable situation. The citizens and members of the judiciary that have a faith commitment to the God revealed in the book of Deuteronomy, can expect the blessing of the Lord to ensue, if justice prevails.

By doing all of this, the Rainbow Nation can ensure that justice is served by everyone and for everyone.

\section{Acknowledgements Competing interests}

The author declares that they have no financial or personal relationships that may have inappropriately influenced them in writing this article.

\section{Author's contribution}

A.J.C. is the sole author of this research article.

\section{Ethical considerations}

This article followed all ethical standards for research without direct contact with human or animal subjects.

\section{Funding information}

This research received no specific grant from any funding agency in the public, commercial or not-for-profit sectors.

44.For the jurisdiction of the Constitutional Court, its composition and the appointment of its judges as well as its independence see Venter (2020:175-177). 


\section{Data availability}

Data sharing is not applicable to this article as no new data were created or analysed in this study.

\section{Disclaimer}

The views and opinions expressed in this article are those of the author and do not necessarily reflect the official policy or position of any affiliated agency of the author.

\section{References}

Block, D.I., 2012, Deuteronomy: The NIV Application Commentary, Zondervan, Grand Rapids, MI.

Brown, F., Driver, S.R. \& Briggs, C.A., 1977, Enhanced Brown-Driver-Briggs Hebrew and English Lexicon, Clarendon Press, Oxford.

Brueggemann, W., 2001, Deuteronomy: Abingdon Old Testament Commentaries, Abingdon Press, Nashville, TN.

Carrière, J.-M., 2001, Théorie du politique dans le Deutéronome: Analyse des unités, des structures et des concepts de Dt 16,18-18,22, Peter Lang, Frankfurt am Main. (Österreichische biblische Studien 18).

Christensen, D.L., 2001, Deuteronomy 1:1-21:9: Word Biblical Commentary, Thomas Nelson Publishers, Nashville, TN.

Coetsee, A.J., 2019, 'YHWH and Israel in terms of the concept of life in Deuteronomy' Old Testament Essays 32(1), 101-126. https://doi.org/10.17159/2312-3621/ 2019/v32n1a7

Cole, R.D., 2000, Numbers: New American Commentary, Broadman \& Holman, Nashville, TN.

Craigie, P.C., 1976, The Book of Deuteronomy: New International Commentary on the Old Testament, Eerdmans, Grand Rapids, MI.

Durham, J.I., 1987, Exodus: Word Biblical Commentary, Word Books, Waco, TX.

Flatto, D.C., 2018, 'Constructing justice: The selective use of Scripture in formulating early Jewish accounts of the courts', Harvard Theological Review 111(4), 488-515. https://doi.org/10.1017/S001781601800024X

Frymer-Kenski, T., 2003, 'Anatolia and the Levant: Israel', in R. Westbrook (ed.), A history of ancient Near Eastern Law, vol. 1, pp. 975-1046, Brill, Leiden.

Gesenius, F.W., 1910, Gesenius' Hebrew grammar, 2nd edn., Claredon Press, Oxford.

Gesenius, W. \& Tregelles, S.P., 2003, Gesenius' Hebrew and Chaldee lexicon of the Old Testament Scriptures, Logos Bible Software, Bellingham, WA

Hoexter, C. \& Olivier, M., 2014, The judiciary in South Africa, Juta, Cape Town.
Jenni, E. \& Westermann, C. (eds.), 1997, Theological lexicon of the Old Testament, transl. M.E. Biddle, Hendrickson Publishers, Peabody, MA.

Lohfink, N., 1993, 'Distribution of the functions of power: The laws concerning public offices in Deuteronomy 16.18-18.22', in D.L. Christensen (ed.), A song of power and the power of song: Essays on the book of Deuteronomy, pp. 336-352, Eisenbrauns, Winona Lake, IN. (Sources for Biblical and Theological Study 3).

Lundbom, J.R., 2013, Deuteronomy: A Commentary, Eerdmans, Grand Rapids, MI.

McConville, J.G., 2002, Deuteronomy: Apollos Old Testament Commentary, Apollos, Leicester.

Merrill, E.H., 1994, Deuteronomy: The New American Commentary, Broadman \& Holman, Nashville, TN.

Morrow, W.S., 1995, Scribing the center: Organization and redaction in Deuteronomy 14:1-17:13, Scholars Press, Atlanta, GA. (Society of Biblical Literature Monograph Series 49).

Müller, R., 2013, 'The blinded eyes of the wise: Sapiental tradition and Mosaic commandment in Deut 16:19-20', in B.U. Schipper \& D.A. Teeter (eds.), Wisdom and Torah: The reception of 'Torah' in the wisdom literature of the Second Temple Period, pp. 9-33, Brill, Leiden.

O'Brien, M., 2008, 'Deuteronomy 16:18-18.22: Meeting the challenge of towns and nations', Journal for the Study of the Old Testament 33(2), 155-172. https://doi. org/10.1177/0309089208099254

Olson, D.T., 2007, 'Between humility and authority: The interplay of the judge-prophet laws (Deuteronomy 16:18-17:13) and the judge-prophet narratives of Moses', in M.D. Carrol \& J.E. Lapsley (eds.), Character ethics and the Old Testament: Moral dimensions of Scripture, pp. 51-61, Westminster John Knox Press, Louisville, KT.

Otto, E., 2016, Deuteronomium 12-34, Erster Teilband: 12,1-23,15, Herder, Freiburg im Breisgau. (Herders Theologischer Kommentar zum Alten Testament).

Rofé, A., 2001, 'The organization of the judiciary in Deuteronomy (Deut. 16.18-20 17.8-13; 19:15; 21:22-3; 24:16; 25:1-3)', in P.M. Michèle Daviau, J.W. Wevers \& M. Weigl (eds.), The World of the Aramaeans 1: Biblical studies in honour of PaulEugène Dion, Journal of the Study of the Old Testament Supplement Series 324 pp. 92-112, Sheffield Academic Press, Sheffield.

Tigay, J.H., 1996, The JPS Torah Commentary: Deuteronomy, Jewish Publication Society, Philadelphia, PA.

VanGemeren, W.A. (ed.), 1997, New International Dictionary of Old Testament Theology \& Exegesis, 5 vols., Zondervan, Grand Rapids, MI.

Venter, F., 2020, 'Independence and accountability of the South African judiciary', in E.H. Ballin, G. van der Schyff \& M. Stremler (eds.), European yearbook of constitutional law 2019, Judicial power: Safeguards and limits in a democratic society, pp. 171-196, Asser Press, The Hague. (European Yearbook of Constitutional Law, vol. 1).

Vogt, P.T., 2006, Deuteronomic theology and the significance of Torah: A reappraisal, Eisenbrauns, Winona Lake, IN.

Weinfeld, M., 1977, 'Judge and officer in ancient Israel and in the ancient New East', in G. Goldenberg (ed.), Israel oriental studies VII, pp. 65-88, Tel Aviv University, Tel Aviv.

Wright, C.J.H., 1996, Deuteronomy: New International Biblical Commentary, Hendrickson Publishers, Peabody, MA. 